\title{
Cover for wildlife after summer grazing on Sandhills rangeland
}

\author{
PATRICK E. REECE, JERRY D. VOLESKY, AND WALTER H. SCHACHT
}

Authors are associate professor, University of Nebraska, Panhandle Research and Extension Center, 4502 Avenue I, Scottsbluff, Neb. 69361; assistant pro-

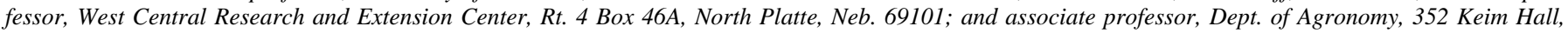
Lincoln, Neb. 68583.

\begin{abstract}
Livestock production and wildlife habitat objectives become antagonistic on grasslands when the architecture of standing herbage needed for key wildlife species limits the amount of forage that can be used by livestock. However, quantitative information needed to achieve cover objectives for wildlife is not available for summer-grazed grasslands. Three replicates of 7 grazing treatments were applied to the same 1.0-ha pastures for 3 years. Treatments included ungrazed control, and grazing at 16, 32, or 48 animal unit days (AUD) ha $^{-1}$ for 5 to 7 days during mid-June or mid-July. Cover was estimated after killing frost in September by measuring the average height below which complete visual obstruction occurred. Cumulative grazing pressure (AUD $\mathrm{Mg}^{-1}$ ) was used to describe grazing effects because of measurable differences in herbage among pastures and dates. Grazing in June reduced the average height of autumn cover at a constant rate from 11.0 to $7.0 \mathrm{~cm}\left(\mathbf{R}^{2}=\mathbf{0 . 3 4}\right)$ as cumulative grazing pressure increased from 16 to $90 \mathrm{AUD} \mathrm{Mg}^{-1}$. In contrast, declines in cover after grazing in July were about 2.6 times greater for cumulative grazing pressures up to $40 \mathrm{AUD} \mathrm{Mg}^{-1}\left(\mathbf{R}^{2}\right.$ $=0.62$ ), indicating a measurable decline in plant growth and an increasing dependence of autumn cover on the remaining herbage when grazing ended. Relatively low predictability of autumn cover after June compared to July grazing was offset by more plant growth during the balance of the growing season. Frequency of low-cover patches $(\leq \mathbf{5 . 0} \mathrm{cm})$ within pastures was highly correlated $\left(R^{2}=0.94\right)$ with mean estimates of autumn cover. Consequently, the quality of cover near potential nesting sites also declined as the average height of cover declined, regardless of grazing date. The interdependence of low-cover patches and mean visual obstruction indicates that either variable could be the primary criterion for nest site selection up to 12 cm in visual obstruction.
\end{abstract}

Key Words: autumn visual obstruction, grazing pressure, sharptailed grouse (Tympanuchus phasianellus) habitat

The relationship between livestock and rangeland wildlife habitat is dynamic. Herbage is the primary source of nutrients for livestock and the only source of nesting cover for many grassland

Research was funded by the Anna H. Elliott Fund, University of Nebraska Foundation and in-kind support from the USDA, Nebraska National Forest. Published as Paper 12925, Journal Series, Nebraska Agricultural Research Division.

The authors wish to thank Andrew P. Cullan, Gordon D. Moeller, Troy M. Walz, and Alexander J. Smart of the University of Nebraska and Virginia Emly, Herb Gerhard, Tom Landel, and Cindy Schipporeit of the USDA, Nebraska National Forest for technical assistance in the field, Sharon Holman for preparation of the text, and Ann E. Koehler for preparation of graphics.

Manuscript accepted 10 May 2000.

\section{Resumen}

Los objetivos del manejo del hábitat para la fauna silvestre y la producción de ganado vienen a ser antagónicos cuando la arquitectura de la vegetación en pie necesaria para las especies clave de fauna silvestre limita la cantidad de forraje que puede ser usada por el ganado. Sin embargo, la información cuantitativa necesaria para alcanzar los objetivos de cobertura para la fauna silvestre no esta disponible para pastizales de verano. Durante 3 años, 3 repeticiones de 7 tratamientos de apacentamiento se aplicaron en los mismos potreros de 1.0 ha. Los tratamientos incluían el control sin apacentamiento y el apacentamiento a 16, 32 y 48 unidad-animal-días (UAD) ha ${ }^{-1}$ por 5 a 7 días a mediados de junio o mediados de julio. La cobertura se estimó después de la primer helada de septiembre midiendo la altura promedio abajo de la cual ocurrió la obstrucción visual completa. Se utilizó la presión de apacentamiento acumulativa (UAD $\mathrm{Mg}^{-1}$ ) para describir los efectos del apacentamiento debidos a diferencias medibles de forraje entre potreros $y$ fechas. El apacentamiento en Junio redujo la altura promedio de la cobertura de otoño a una tasa constante de 11 a $7 \mathrm{~cm}\left(\mathbf{R}^{2}=0.34\right)$ conforme la presión de apacentamiento acumulativa se incremento de 16 a 90 UAD $\mathrm{Mg}^{-1}$. En contraste, las disminuciones de cobertura después del apacentamiento en Julio fueron cerca de 2.6 veces ma para las presiones de apacentamiento acumulativas hasta de 40 UAD $\mathrm{MG}^{-1}\left(\mathrm{R}^{2}=0.62\right)$, indicando una disminución medible en el crecimiento de las plantas $y$ una dependencia en aumento de la cobertura de otoño en el forraje remanente cuando el apacentamiento termino. La relativamente baja predictibilidad de la cobertura de otoño después de Junio comparada con el apacentamiento de Julio fue neutralizada por un mayor crecimiento vegetal durante el balance de la estación de crecimiento. La frecuencia de parches de baja cobertura $(\# 5.0 \mathrm{~cm})$ dentro de los potreros estuvo altamente correlacionada $\left(R^{2}=0.94\right)$ con la media de las estimaciones de la cobertura de otoño. Consecuentemente, la calidad de la cobertura cerca de sitios potenciales para anidamiento también disminuyó conforme la altura de la cobertura se redujo, independientemente de la fecha de apacentamiento. La interdependencia de parches de baja cobertura y la media de obstrucción visual indica que cualquier variable puediera ser el criterio principal para la selección de sitios de anidamiento hasta de $12 \mathrm{~cm}$ en obstrucción visual.

bird species. Herbage allocation decisions are important each year. Standing herbage after grazing and plant growth during the balance of the growing season are the only sources of cover when birds search for nesting sites early in the following spring. The quality of nesting cover on grasslands declines as stocking rate increases (Duebbert et al. 1986, Kie et al. 1996). Grazing management strategies that provide adequate cover for establishment 
of successful nest sites in early spring increase mean clutch size of many grassland bird species (Kantrud and Higgins 1992, Fredrickson 1996) and allow chicks to develop before peak summer heat stress and mature before harsh fall weather conditions occur. Cumulative grazing pressure, date of grazing, precipitation, and kind and distribution of plant species are important variables in understanding the effects of grazing management decisions on cover for wildlife (Schroeder and Braun 1992). However, there is no published quantitative information that can be used to manage summer grazing to obtain target levels of autumn cover in grass dominated ecosystems.

The Sandhills of Nebraska which encompass about 3.9 million ha of native grassland, are home to the largest populations of sharp-tailed grouse (Tympanuchus phasianellus) in the United States. Sharptailed grouse and many other species of grassland birds select nest sites from late March to early June in the Nebraska Sandhills (Duebbert et al. 1986, Fredrickson 1996). Nesting and brood rearing cover are the most limiting habitat factors for sharptailed grouse through much of the Sandhills (Prose 1987). Our objective was to quantify the effects of grazing pressure in June or July, precipitation, and the frequency of occurrence of selected plant species on nesting cover, based on visual obstruction (VO) measurements after killing frost in September.

\section{Materials and Methods}

The study was conducted on sands range sites in good to excellent condition at the University of Nebraska, Gudmundsen Sandhills Laboratory $\left(42^{\circ} 07^{\prime} \mathrm{N}, 101^{\circ} 43^{\prime}\right.$ W) located near Whitman, Neb. Prairie sandreed [Calamovilfa longifolia (Hook) Scribn.], sand bluestem (Andropogon hallii Hack), and little bluestem (Andropogon scoparius Michx.) were co-dominant species on these sites (Great Plains Flora Association 1986). The long-term, 30-yr average annual precipitation is $56 \mathrm{~cm}$ (National Oceanic and Atmospheric Administration 1997). Soils are Valentine fine sands (mixed, mesic Typic Ustipsamments).

Experimental units were individual 1.0ha pastures. Twenty-one pastures were separated into 3 blocks based on frequency of occurrence of plant species in fifty, $0.25-\mathrm{m}^{2}(50 \times 50 \mathrm{~cm})$ quadrats randomly located in uniformly spaced belt transects in each pasture in May 1995. Occurrence of hairy grama (Bouteloua hirsuta Lag.), little bluestem, prairie sandreed, and sand bluestem in nested $0.05 \mathrm{~m}^{2}$ and $0.01 \mathrm{~m}^{2}$ areas within the $0.25-\mathrm{m}^{2}$ quadrat also was recorded. Seven grazing treatments were randomly allotted to pastures within each block. Treatments consisted of an ungrazed control, grazing at light, moderate, or heavy seasonal stocking rates, 16, 32, or 48 animal unit days (AUD) $\mathrm{ha}^{-1}$, for 5 to 7 days in mid-June or mid-July. Grazing treatments were applied to the same pastures in each summer from 1995 through 1997. Yearling cattle were weighed after an overnight stand without food and water and allocated to treatments by weight to provide equal total weights of cattle for replications within stocking rate treatments. Animal weights were divided by $454 \mathrm{~kg}$ to estimate animal unit (AU) equivalents. The number of yearlings per pasture ranged from 4 to 12 . Pastures in this study had previously been used for grazing research from 1988 to 1991 (Reece et al. 1996). All pastures were rested in 1992 and 1994. Pastures were stocked at 49 AUD ha-1 from June to October 1993.

Before grazing treatments were applied, current-year standing herbage was estimated by clipping all vegetation at ground level in ten, 25 x 100-cm randomly located quadrats per pasture. Based on repeated observations in these pastures during a previous study, Northup (1993) reported that six weeks fescue, (Festuca octoflora Walt.), green sagewort (Artemisia dracunculus L.), western ragweed (Ambrosia psilostachya DC.), prickly pears (Opuntia spp. P. Mill.), pincushion cactus [(Coryphantha vivipara (Nutt.) Britt. \& Rose], and prairie wild rose (Rosa arkansana Porter) were not grazed or were rarely grazed by cattle in June or July. These species and all previous year's growth were discarded. The remaining herbage was oven dried at $60^{\circ} \mathrm{C}$ for 48 hours and weighed to the nearest $0.1 \mathrm{~g}$ to determine dry matter yield. Grazing pressure was expressed as AUDs per metric ton of current-year palatable herbage (AUD $\mathrm{Mg}^{-1}$ ) measured at the beginning of grazing periods.

Autumn cover for birds was estimated by measuring visual obstruction (VO) in late September, after killing frost, at a randomly selected point within 48 uniformly spaced areas in each pasture. Equipment used to measure VO was similar in design to that used by Robel et al. (1970). Two, 3 x $120-\mathrm{cm}$ poles were connected by a $4-\mathrm{m}$ nylon cord fastened at a height of $1 \mathrm{~m}$ on each pole. The reading pole was painted in 36 alternating $2.54-\mathrm{cm}$ wide bands of gray and white, numbered in ascending order with 1 at the bottom. The reading pole was held vertically at sample points while a second person placed the sight pole at a distance of $4 \mathrm{~m}$ and recorded the number of the lowest band not fully obstructed by vegetation when viewed from a height of $1.0 \mathrm{~m}$ on the sight pole. Means of $2 \mathrm{VO}$ readings taken on the contour from opposite sides of each sample point were used for analysis.

A $2 \times 3$ factorial array of grazing dates and stocking rates was used to produce a wide range in cumulative grazing pressure. Ungrazed control data $(n=9)$ were combined with data from grazed pastures for each month $(n=27)$ and months were analyzed separately $(n=36)$ with regression analysis (SAS 1985) to evaluate the univariate effects of cumulative grazing pressure on mean visual obstruction of individual pastures. The entire data set from 21 pastures over 3 years $(n=63)$ was used in regression analysis to determine the relationship between frequency of lowcover patches $(\mathrm{VO} \leq 5.0 \mathrm{~cm})$ and mean visual obstruction in pastures after killing frost in September. Additionally, the stepwise procedure (SAS 1985) was used to conduct a regression analysis on the multivariate effects of cumulative grazing pressure, precipitation in individual or multiple months within years, and frequency of occurrence of selected grass species on visual obstruction in the autumn after grazing in June or July $(n=27)$ and for ungrazed pastures $(n=9)$.

\section{Results and Discussion}

Visual obstruction (VO) in ungrazed control pastures declined $11 \%$ from 12.3 $\mathrm{cm}$ in 1995 to $11.0 \mathrm{~cm}$ in 1996 and $15 \%$, to $9.3 \mathrm{~cm}$, from 1996 to 1997 . These declines corresponded to progressively lower cumulative precipitation each year (Fig. 1). Most of the differences in cumulative precipitation among years summarized in Figure 1 occurred during May and June because differences among years were relatively small at the end of April. Measurable differences in soil moisture during May and June would cause measurable differences in current-year herbage in autumn (Dahl 1963). Similar declines in autumn cover in ungrazed control pastures from 1995 to 1996 and from 1996 to 1997 when precipitation declined $30 \%$ compared to $9 \%$ between years indicated that carryover herbage from preceding years moderated changes in cover between 1995 and 1996. Additionally, the relationship 


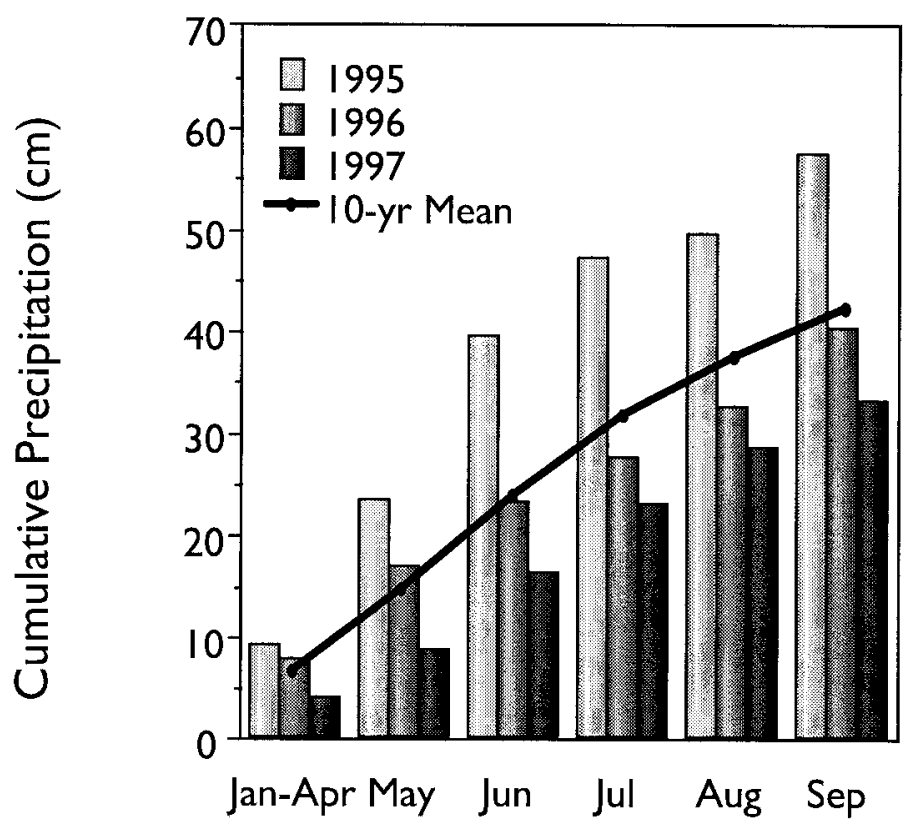

Fig. 1. Cumulative precipitation during 1995, 1996, and 1997 at the Gudmundsen Sandhills Laboratory, near Whitman, Nebr.

between VO and current-year herbage in the autumn was examined in a concurrent study in the same pastures. The relatively small amount of variation in autumn cover among pastures accounted for by currentyear herbage during 1995 to 1997 (Volesky et al. 1999) further supported the conclusion that carryover herbage has a measurable effect on autumn cover.

\section{Grazing Pressure}

Three levels of stocking rate and measurable differences in palatable herbage among pastures and years resulted in a wide range of grazing pressure within each month (Fig. 2). Mean yields of palatable, current-year herbage immediately before application of grazing treatments were 787,582 , and $645 \mathrm{~kg} \mathrm{ha}^{-1}$ in May and $1,364,1,347$, and $863 \mathrm{~kg} \mathrm{ha}^{-1}$ in July during 1995, 1996, and 1997, respectively. Grazing pressure accounted for about twice as much of the variation in autumn cover among pastures after July grazing $\left(\mathrm{R}^{2}=0.62\right)$ compared to June grazing $\left(\mathrm{R}^{2}\right.$ $=0.34)$. Rapid plant growth from midJune to mid-July offset the effects of relatively heavy grazing pressure on standing herbage over a wide range in species composition (Cullan et al. 1999). Visual obstruction declined by $1 \mathrm{~cm}$ for each 23 AUD $\mathrm{Mg}^{-1}$ increase in cumulative grazing pressure in June. In contrast, VO after grazing in July declined about $1 \mathrm{~cm}$ for each 9 AUD $\mathrm{Mg}^{-1}$ increase in cumulative grazing pressure up to 40 AUD $\mathrm{Mg}^{-1}$ after which little change occurred. This concurs with an exponential decline in cover as summer stocking rates increased during June to September on mixed prairie in North Dakota (Duebbert et al. 1986).

Our results indicate that the amount of standing herbage remaining after grazing Sandhills pastures in July is a critical factor in determining the quality of cover for wildlife after killing frost. Distribution and architecture of carryover herbage and differences in plant density may be important factors when selecting pastures to provide adequate cover on a percentage of the landscape. The likelihood of livestock consuming carryover herbage during the summer increases as grazing pressure increases and as plants mature. If all palatable current-year herbage was readily available to livestock, $50 \%$ use would occur between 61 and 42 AUD $\mathrm{Mg}^{-1}$ if daily dry matter intake ranged from 1.8 to $2.6 \%$ of body weight, respectively. However, a percentage of the current-year herbage is frequently obscured by carryover herbage with relatively low nutritive value. Differences in nutritive value of carryover and current-year herbage decline as plants mature. Numerous field observations during October and November at the Gudmundsen Sandhills Laboratory indicate that dormant-season herbivory primarily affects leaf tissue leaving a relatively high percentage of elongated tillers, regardless of age. Average height of visual obstruction will decline with dormant-season grazing even though the maximum height of herbage may not change.
Architecture of the remaining herbage in winter-grazed pastures may play a complementary role in providing adequate levels of cover in the autumn following summer grazing.

The habitat suitability index proposed for sharp-tailed grouse (Prose 1987) assigns a nesting cover value of 0 when average visual obstruction is $\leq 5.0 \mathrm{~cm}$ because successful nests have not been observed with less cover. End-of-season visual obstruction for individual pastures was above $5 \mathrm{~cm}$ regardless of stocking rate or date of grazing in our study (Fig. 2). However, sharp-tailed grouse populations are at risk in areas with minimal cover because of relatively low levels of nesting success and the potential for snow induced reductions in cover before nest sites are selected in the spring (Prose 1987).

Wildlife biologists have selected a minimum visual obstruction value of $6.9 \mathrm{~cm}$ for sustaining grouse populations at the Samuel R. McKelvie National Forest, 60 $\mathrm{km}$ northeast of the Gudmundsen Sandhills Laboratory. High levels of cumulative grazing pressure in June resulted in nearly complete use of palatable current-year herbage within the physical limits of livestock herbivory. Plant growth after mid-June provided enough cover to meet this standard after light, moderate, or heavy stocking, 16, 32, or 48 AUD ha-1, except in 2 cases in 1997 when precipitation was $13 \%$ below average. In contrast, end-of-season visual obstruction after moderate stocking in July was $\geq 6.9 \mathrm{~cm}$ only in 1995 when annual precipitation was $34 \%$ above average (Fig. 2).

Repeated heavy use of prairie sandreed during June or July or repeated heavy use of sand bluestem in July in conjunction with below average precipitation will cause measurable reductions in total organic reserves (Reece et al. 1996). Cattle selectively graze prairie sandreed removing about $50 \%$ of its herbage at cumulative grazing pressures of about 28 AUD $\mathrm{Mg}^{-1}$ and $60 \%$ at $40 \mathrm{AUD} \mathrm{Mg}^{-1}$ (Cullan et al. 1999). Deferring grazing to August or later, the year after June grazing would enhance prairie sandreed vigor and avoid jeopardizing nesting success of grassland bird species (Jensen et al. 1990, Paine et al. 1996) because of removal of cover and trampling of nests.

Frequency of low-cover patches $(\mathrm{VO} \leq$ $5 \mathrm{~cm}$ ) with nesting cover values of 0 and average visual obstruction in pastures were highly correlated $\left(\mathrm{R}^{2}=.94\right)$ indicating that the quality of cover near potential nesting sites also declined as the average height of visual obstruction declined in 


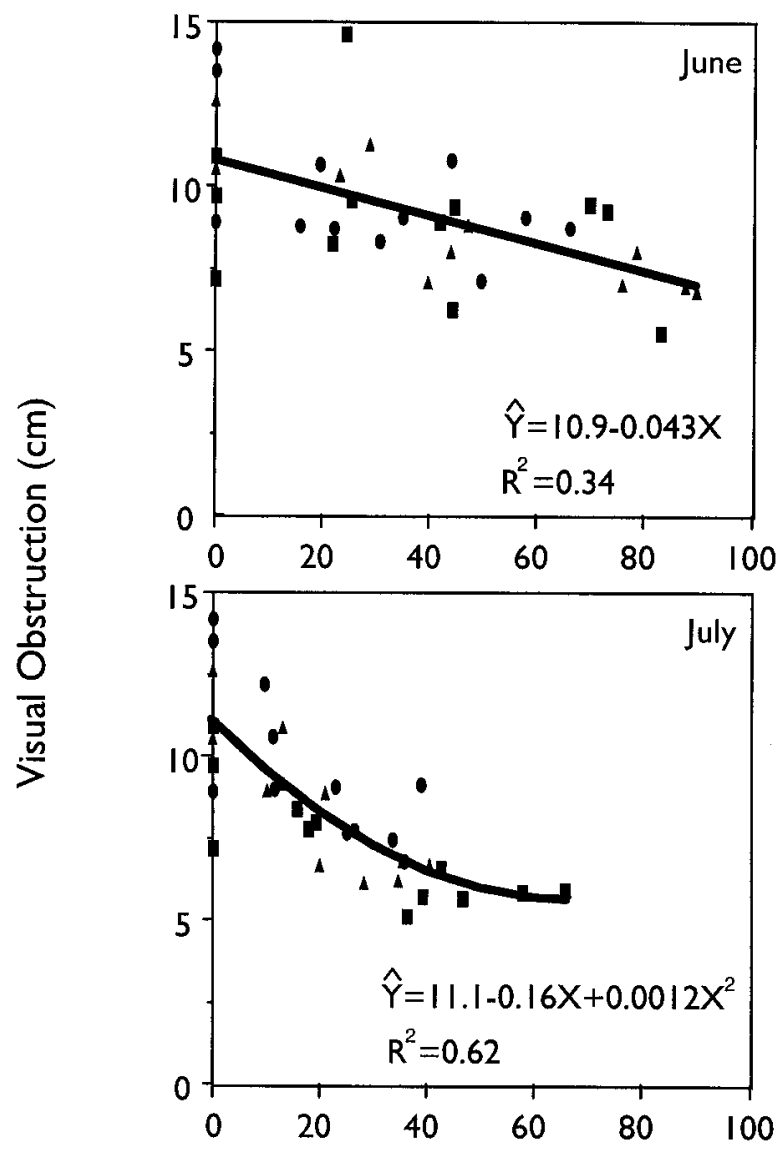

\section{Cumulative Grazing Pressure (AUD $\mathrm{Mg}^{-1}$ )}

Fig. 2. Effects of cumulative grazing pressure in mid-June or mid-July on visual obstruction $(n=$ $36)$ at the end of growing seasons during $1995(n), 1996(\Delta)$, and $1997(\square)$ on sands range sites in good to excellent condition at the Gudmundsen Sandhills Laboratory near Whitman, Nebr. and frequency of occurrence of plant species accounted for $59 \%$ of the variance in autumn cover among ungrazed pastures. The contrast in predictability after grazing in June compared to July corresponds to only a 30-day difference in time from the end of grazing to killing frost. The relatively high diversity of plant species in these pastures (Northup 1993) and the potential for many species to grow rapidly from mid-June to mid-July (Hendrickson et al. 1997, Reece et al. 1999) may have contributed to the greater variability in autumn cover after grazing in June compared to July.

\section{Precipitation}

While annual precipitation ranged from 87 to $134 \%$ of the 10 -year average, most of the differences in precipitation among years occurred during May and June (Fig. 1). Differences in cumulative precipitation among years were relatively small at the end of April. Precipitation during May was about $14 \mathrm{~cm}$ in $1995,9 \mathrm{~cm}$ in 1996 , and $5 \mathrm{~cm}$ in 1997. June precipitation was about $16 \mathrm{~cm}$ in 1995 compared to $7 \mathrm{~cm}$ in 1996 and 1997. However, only May precipitation was selected from all possible single and multiple month combinations (Table 1).

May precipitation accounted for $32 \%$ of the variation in cover among ungrazed control pastures and $11 \%$ of the variation among July-grazed pastures during 3 years. In contrast, precipitation had no measurable effect on autumn cover when pastures pastures, regardless of grazing date (Fig. 3 ). During a 3-year period, frequency of low-cover patches declined by about 10 percentage points for each $1-\mathrm{cm}$ increase in visual obstruction from $63 \%$ at $5 \mathrm{~cm}$ to $12 \%$ at $10 \mathrm{~cm}$, approaching $0 \%$ after 12 $\mathrm{cm}$ regardless of grazing treatments (Fig. 3 ). About $38 \%$ of sample areas were lowcover patches when average visual obstruction in pastures was at the standard of $6.9 \mathrm{~cm}$. The interdependence of lowcover patches and mean visual obstruction in our study indicates that either one of these habitat characteristics could be the primary criterion for nest site selection up to $12 \mathrm{~cm}$ in $\mathrm{VO}$.

\section{Multivariate Effects}

Collectively, grazing pressure, precipitation, and/or frequency of occurrence of plant species accounted for $46 \%$ of the variance in autumn cover among Junegrazed pastures and $81 \%$ when pastures were grazed in July (Table 1). Precipitation

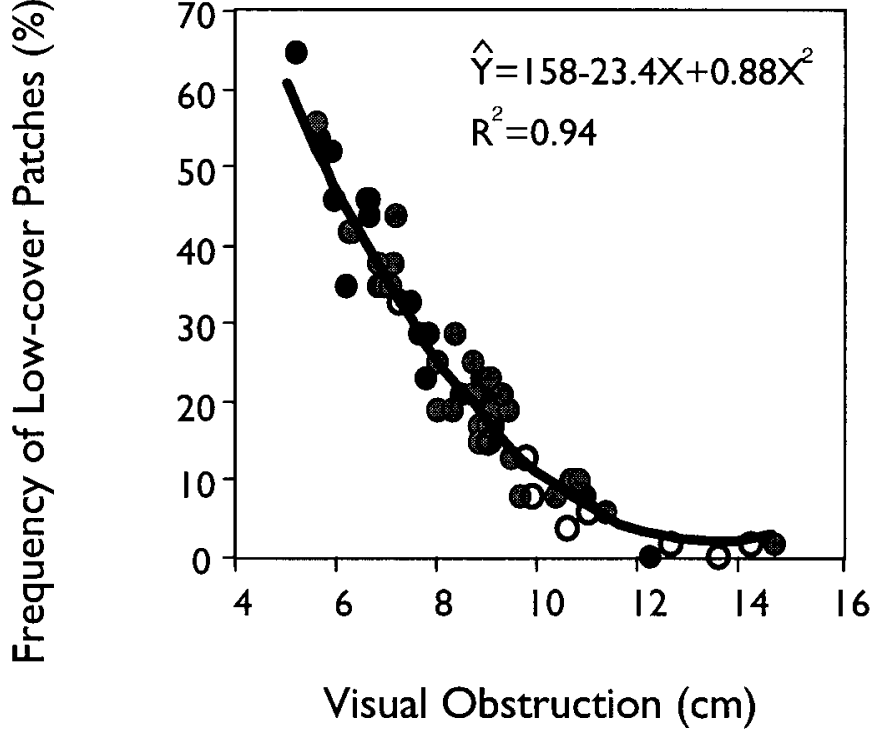

Fig. 3. Relationship between the frequency of low-cover patches with visual obstruction $\leq 5 \mathrm{~cm}$ and mean visual obstruction for 1.0-ha pastures $(n=63)$ after killing frost in September for June-grazed $(n)$, July-grazed $(n)$, and ungrazed control $(\bigcirc)$ pastures at the Gudmundsen Sandhills Laboratory near Whitman, Nebr., during 1995 to 1997. 
were grazed in June. During previous grazing studies in the same pastures, the percentage of current-year palatable herbage composed of cool-season species in midJune ranged from 9 to $20 \%$ (Northup 1993). Moderate to heavy use of cool-seaincreased the availability of soil moisture and nutrients to warm-season plant species.

\section{Plant Species}

Frequency of occurrence of hairy grama in $0.01-\mathrm{m}^{2}$ quadrats was associated with $27 \%$ of the variation in cover among control pastures during 3 years (Table 1). The positive relationship between a short-grass species and visual obstruction in this study was related to the positive correlation $(\mathrm{P}<$ 0.001 ) between the occurrence of hairy grama and 2 tallgrass species, prairie sandreed $\left(r^{2}=0.41\right)$ and sand bluestem $\left(r^{2}=\right.$ $0.50)$. In the absence of grazing, differences in cover associated with plant communities were similar to those associated (Table 1). son species in mid-June may have with precipitation differences among years

Vegetation had the least effect on cover in July-grazed pastures with the frequency of occurrence of prairie sandreed associated with only $4 \%$ of the variation in mean visual obstruction among pastures compared to $66 \%$ of the variation accounted for by grazing pressure (Table 1). Prairie sandreed is a rhizomatous tallgrass characterized by populations of dispersed tillers and a relatively low frequency of reproductive culms per unit area compared to mid and tall bunchgrasses (Weaver 1965). However, when precipitation was $134 \%$ of average in 1995 , density of prairie sandreed tillers increased as cumulative grazing pressure increased in July-grazed pastures compared to ungrazed control pastures (Cullan et al. 1999). Increases in tiller densities that occurred in 1995 were not sustained in the following year when precipitation was near average. Increases in cover that corresponded to occurrence of prairie sandreed may also be related to other plant species because high frequencies of occurrence of prairie sandreed are associated with high seral stages charac-

Table 1. Variables and partial $\mathbf{R}^{2}$ values for multiple regression equations for autumn visual obstruction in ungrazed control, June-grazed, and July-grazed pastures based on stepwise selection from cumulative grazing pressure, precipitation during individual and multiple months of each year and frequency of occurrence of selected grass species.

\begin{tabular}{|c|c|c|c|c|}
\hline \multicolumn{2}{|c|}{ Dependent Variables ${ }^{1}$} & Control & June & July \\
\hline & & & (partial & \\
\hline \multicolumn{2}{|c|}{ Grazing pressure (G) } & - & .29 & .66 \\
\hline \multicolumn{2}{|c|}{ May precipitation (M) } & .32 & - & .11 \\
\hline \multicolumn{2}{|c|}{ Hairy grama $(\mathrm{H})$} & .27 & - & - \\
\hline \multicolumn{2}{|c|}{ Little bluestem (L) } & - & .17 & - \\
\hline \multicolumn{2}{|c|}{ Prairie sandreed $(\mathrm{P})$} & - & - & .04 \\
\hline & & & .59 & 46.81 \\
\hline Control & \multicolumn{4}{|c|}{$\mathrm{Y}=6.0+0.3 \mathrm{M}+0.0089 \mathrm{H}^{2}$} \\
\hline June & \multirow{2}{*}{\multicolumn{4}{|c|}{$\mathrm{Y}=9.6-0.039 \mathrm{G}+0.001 \mathrm{~L}^{2}$}} \\
\hline July & & & & \\
\hline
\end{tabular}

In June-grazed pastures, the frequency of occurrence of little bluestem in $0.05-\mathrm{m}^{2}$ quadrats was associated with $17 \%$ of the variation in autumn cover among pastures during 3 years (Table 1). Increases in visual obstruction related to increases in little bluestem may be directly related to the foliar architecture of this species. This warm-season bunchgrass is characterized by the accumulation of relatively high densities of 30 to $50 \mathrm{~cm}$ tall reproductive culms from past years. Carryover of several residual reproductive culms in a bunch causes measurable reductions in the use of current-year little bluestem herbage by cattle (Brummer 1994). terized by a greater abundance of mid and tallgrass species with the potential to contribute directly to visual obstruction.

Mean frequencies of occurrence for pastures ranged from 10 to $20 \%$ for hairy grama, 18 to $48 \%$ for little bluestem, and from 86 to $98 \%$ for prairie sandreed. Based on multivariate regression equations, variables associated with differences in the distribution of plant species among pastures could change end-of-season visual obstruction values by $2.7 \mathrm{~cm}$ in ungrazed pastures, $2.0 \mathrm{~cm}$ in June-grazed pastures, and $1.3 \mathrm{~cm}$ in July-grazed pastures. Additionally, the quadratic relationship between visual obstruction and fre- quency of occurrence for all 3 species (Table 1) indicated relatively small differences in the distribution of plant species accounted for measurable differences in the ability of pastures to produce cover under the same grazing treatment.

Autumn cover was unexpectedly high in ungrazed control pastures after a $30 \%$ reduction in annual precipitation during the second year. Given the concurrent and uniformly spaced declines in May precipitation, selected in multivariate regression analysis, and uniformly spaced declines in autumn cover on ungrazed control pastures, precipitation in this study may have been confounded with the progressive decline in carryover herbage that accumulated during 2 years of rest before this study was initiated. Additionally, the concurrent lack of precipitation effects and relatively high amount of variation in autumn cover among June-grazed pastures accounted for by the frequency of occurrence of little bluestem may have been linked to this confounded relationship. Accumulation and duration of carryover herbage are often greater for little bluestem than any other species in the Sandhills (Brummer 1994). Selection of different plant species for each grazing treatment in multivariate analysis, the inability of hairy grama to directly affect cover, and the potential confounding of little bluestem with carryover herbage, indicate a need for caution when using frequency of occurrence of plant species to predict autumn cover. Future research on "indicator" plant species for wildlife cover should include pastures with a wide range in average carryover herbage at the beginning of the study and annual quantification of carryover herbage.

Results of our study are most applicable where limited variation in landscape or relatively high stocking densities result in uniform distribution of grazing. Best management practices for wildlife habitat and plant vigor should be integrated to enhance herbage production and accomplish resource management objectives. About $90 \%$ of the visual obstruction values for June-grazed pastures met or exceeded the minimum cover standard $(6.9 \mathrm{~cm})$ for sustaining sharp-tailed grouse populations in this area, regardless of stocking rate. In contrast, only light stocking rates consistently produced acceptable levels of autumn cover after grazing in July. Light to moderate stocking rates in June or July and changing the date of grazing by 60 days or more the year after early summer grazing may be necessary to 
reduce the risk of low vigor in prairie sandreed and sand bluestem (Reece et al. 1996). Increased amounts of residual standing herbage from periodic years of rest may allow pastures to be grazed at moderate stocking rates in July when annual precipitation is average or below average and still provide adequate levels of nesting cover the following spring. Additionally, periodically providing full growing season deferment and grazing only during the dormant season will enhance vigor in prairie sandreed and sand bluestem (Reece et al. 1996).

Managing grazing for sharp-tailed grouse nesting cover in all pastures would require a measurable reduction in stocking rates traditionally used in range livestock enterprises, however, it may not be necessary to provide cover over the entire landscape. Sharp-tailed grouse populations can be sustained when high quality cover is well distributed within their home range of 10 to $50 \mathrm{~km}^{2}$ to optimize the carryover of adults needed to sustain populations (Sisson 1976). In the absence of livestock, weathering during the dormant season, may lower visual obstruction below levels considered adequate for sustaining wildlife populations. Given the lack of predictability of weather related losses in cover from autumn to spring, the relative value of increasing autumn cover standards to reduce the intermittent risk of inadequate nesting cover in early spring, should be weighed against the effects of consistently lower stocking rates on livestock enterprises.

\section{Literature Cited}

Brummer, J. E. 1994. Effect of carryover herbage on utilization of little bluestem. Ph.D. Diss. Univ. of Nebraska, Lincoln, Neb.

Cullan, A.P., P.E. Reece, and W.H. Schacht. 1999. Early-summer grazing effects on defoliation and tiller demography of prairie sandreed. J. Range Manage. 52:440-446.

Dahl, B.E. 1963. Soil moisture as a predictive index to forage yield for the Sandhills range type. J. Range Manage. 16:128-132.

Duebbert, H. F., J. T. Lokemoen, and D. E. Sharp. 1986. Nest sites of ducks in grazed mixed-grass prairie in North Dakota. Prairie Nat. 18:99-108.

Fredrickson, L. 1996. Prairie grouse nesting, nest vegetation, and roost vegetation, 19861988. S.D. Dept. Game, Fish, and Parks. Wildl. Div. Completion Rep. No. 96-03.

Great Plains Flora Association. 1986. Atlas of the flora of the Great Plains. T. M. Barkley (ed.). Iowa State Univ. Press. Ames, Iowa.

Hendrickson, J. R., L. E. Moser, K. J. Moore, and S. S. Waller. 1997. Leaf nutritive values related to tiller development in warm-season grasses. J. Range Manage. 50:116-122.

Jensen, H. P., D. Rollins, and R. L. Gillen. 1990. Effects of cattle stock density on trampling loss of simulated ground nests. Wildl. Soc. Bull. 18:71-74.

Kantrud, H. A. and K. F. Higgins. 1992. Nest and nest site characteristics of some groundnesting, non-passerine birds of northern grasslands. Prairie Nat. 24:67-84.

Kie, J. G., V. C. Bleich, A. L. Medina, J. D. Yoakum, and J. W. Thomas. 1996. Managing rangelands for wildlife, $p$. 663-668. In: T.A. Bookhout (ed.), Research and management techniques for wildlife and habitats. The Wildlife Society, Bethesda, Md.
National Oceanic and Atmospheric Administration. 1997. Climatology data (Nebraska). Asheville, N.C.

Northup, B. K. 1993. Utilization of native forages of the Nebraska Sandhills by yearling cattle. $\mathrm{Ph}$.D. Diss. Univ. of Nebraska. Lincoln, Neb.

Paine, L., D. J. Undersander, D. W. Sample, G. A. Bartelt, and T. A. Schatteman. 1996. Cattle trampling of simulated ground nests in rotationally grazed pastures. J. Range Manage. 49:294-300.

Prose, B. L. 1987. Habitat suitability index models: Plains sharp-tailed grouse. USDI. Fish and Wildl. Service. Biol. Rep. 82 (10.142).

Reece, P. E., J. E. Brummer, R. K. Engel, B. K. Northup, and J. T. Nichols. 1996. Grazing date and frequency effects on prairie sandreed and sand bluestem. J. Range Manage. 49:112-116.

Reece, P. E., T. L. Holman, and K. J. Moore. 1999. Late-summer forage on prairie sandreed dominated rangeland after spring defoliation. J. Range Manage. 52:228-234.

Robel, R. J., J. N. Briggs, A. D. Dayton, and L. L. Hulbert. 1970. Relationships between visual obstruction measurements and weight of grassland vegetation. J. Range Manage. 23:295-297.

SAS. 1985. User's guide: Statistics. Version 5 Edition. SAS Inst., Inc. Cary, N.C.

Schroeder, M. A. and C. E. Braun. 1992. Seasonal movement and habitat use by greater prairie-chickens in northeastern Colorado. Colorado Division of Wildlife. Spec. Rep. No. 68. 44 p.

Sisson, L. H. 1976. The sharp-tailed grouse in Nebraska: Research study. Neb. Game and Parks Comm., Lincoln. 88 pp.

Volesky, J. D., W. H. Schacht, and P. E. Reece. 1999. Leaf area index, visual obstruction, and standing crop relationships on Nebraska Sandhills rangeland. J. Range Mange. 52:494-499.

Weaver, J. E. 1965. Native vegetation of Nebraska. Univ. of Nebraska Press, Lincoln, Neb. 